\title{
Application Development To Manage Data And Information On Lettuce Production Companies
}

\author{
Totok Pujianto'1), Andre Prayudha1), Irfan Ardiansah"1) \\ ${ }^{\# 1) F a c u l t y ~ o f ~ A g r o-i n d u s t r i a l ~ T e c h n o l o g y, ~ U n i v e r s i t a s ~ P a d j a d j a r a n, ~ B a n d u n g, ~ I n d o n e s i a ~}$
}

E-mail: totok.pujianto@unpad.ac.id

\begin{abstract}
As a producer of lettuce plants, the company X (as a case object) needs to improve the information system more effectively and efficiently in order to support the increase of production. Therefore, it is necessary to build a management information system that provides information quickly and accurately. The implementation of this research using Waterfall Method. This research begins with the analysis of the needs of all users, then designing data flow diagrams, designing databases using SQL, entity relationship diagrams, normalization, the latter is the design of information structures including user interfaces. After that done programming activities using PHP programming language. This app is verified and validated. The information needs of the company are as follows: There are four parties as users of the information system; Information should be submitted and accessible as soon as possible; The manager can view the information of each division; To each division and vice versa; Managers can monitor the service level of marketing division and division of production; Each division can manage data; There needs to be model information about the agenda of each division. The app provides a shared menu for admins and users. Users are managers, marketing divisions, production divisions, and home packaging divisions. Each user has the same menu ie homepage, schedule, and reports. As for the manager plus menu monitoring. The final application prototype gives users satisfactory results. Each user is also given a menu to manage the database with features: inserting, searching, editing, and deleting data. The database comes with a dynamic and flexible user interface as a medium of data exchange and information between relevant divisions and media support in decisionmaking at the managerial level.
\end{abstract}

Keywords - lettuce production, lettuce production database, production information system

\section{INTRODUCTION}

The high demand for high quality vegetables requires optimizing the management of vegetable crop production. Optimization of production management can be done through the application of information technology in accordance with the ability of the company although the application of control systems and automation in the production of plants has been applied in almost every part of engineering with satisfactory results [1].

PT-X is a company engaged in the production of vegetables such as lettuce, tomatoes, cucumber, spinach, pakcoy, kailan, and kale. Lettuce is a vegetable produced every day by the company. Lettuce becomes one of the preferred commodities by this company, because the demand for lettuce is relatively much every month. Therefore, companies seek a good treatment and distribution support so that the production of lettuce can run either in the hope there is a match between the supply with demand.

Lettuce plant produced by PT-X is a hydroponic vegetable produced using Nutrient Film Technique (NFT) method. The use of Nutrient Film Technique (NFT) method is one stepping stone to increase hydroponics production [2][3]. The application of NFT method on lettuce is the application of agricultural engineering science [4]. Agricultural Engineering is an engineering science that is engaged in agriculture to increase added value, efficiency, and effectiveness in activities before, when, and after the farming process is completed [5]. It aims to ensure the quality, continuity of the quantity of supply of agricultural products and become local enablers covering the wider community[5].

Until this research was conducted, lettuce production using NFT method had difficulty in managing the data, which was caused by distant operating area (greenhouse) and still manual data processing. Data transmission and processing still 
use Microsoft Excel ${ }^{\circledR}$ applications, and the absence of interrelated formats among data entities with each other. This method results in data entered late due to the translation and synchronization of data and the difference in data input time of each stage of production.

Management requires a system to help monitor, control, make decisions, and other administrative activities. Management information systems (MIS) can be used as design for specific categories of information systems in management activities [6]. MIS helps provide the option for managerial level with the latest company condition report. This information will be useful for monitoring and controlling the activities of the company and predicting what will happen in the future [7]. This study aims to design an easily manageable database management information system so that: (1) provide information quickly, accurately, ideally, and optimally at the managerial level; (2) know the company's potential map in lettuce production process; and (3) implement information system with database management on the production of lettuce.

\section{MATERIAL AND METHOD}

This study is classified as an engineering activity that is designing and building management information system in the form of website, where activity initially is research activity to an object which in this case is PT.- $X$, while the designing process using waterfall method. Waterfall method commonly used in designing information systems [8][9]. The research is classified as a descriptive research where deep observations cover all related entities and inter-entity relationships [10]. The result is used to design an information system to produce an application program.

This research was conducted to take the object of PT - X is located in West Bandung regency, West Java Province. The timing of the research took place from March 14 to August 31, 2016. Instruments used in the design of this system is XAMPP as an interlocal server, SQL as a database, and PHP as a programming language [11].

The information system has been designed and then verified to check the conformity between the results of the design. At this stage also carried out the previous design development. After that test is done as a validation activity to determine system performance [12]. Verification and validation are done repeated simultaneously in such a way that the result is near perfect and afterwards the implementation of the system on the company
[13]. At the end of the documentation is made as the completeness of the system. Waterfall method consists of several steps, namely: (1) system investigation, (2) system analysis, (3) system design, (4) system implementation, and (5) system maintenance [8]. The stage is an uninterrupted cycle so that the system can be continuously improved as needed and the availability of time of study[9].

\section{A. System Investigation}

The system investigation stage is intended to formulate the problems and opportunities of a condition. Investigative activities include monitoring, selection and preliminary study of the purpose of problem solving in the system with the aim of obtaining a description of the problems in managing information contained in the lettuce production division under the Nutrient Film Technique (NFT) method. The investigation phase of the system includes the planning stage and the feasibility study phase.

\section{Planning Stage}

Information system planning is based on the need of monitoring system to help users to work more effectively and efficiently in reporting monitoring results during the production process [12]. The purpose of information systems design is to know the condition of growth and development of plants during the production process and assist users in taking a decision and action in case of undesirable events. All of information presented quickly and accurately is expected to help the job optimally.

\section{Feasibility Study Stage}

At this stage a brief overview of the main factors that influence the system in achieving the desired objectives. Six system feasibility dimensions include: (1) technical feasibility, (2) economic return, (3) non-economic return, (4) ethical law, (5) operational, and (6) schedule. Technical feasibility states the availability of hardware and software to carry out the required processing. Economic returns state the feasibility of a system to be built, judged in terms of finance by comparing the value of usefulness and cost.

Non-economic returns suggest whether the proposed system is valued on the basis of profits that can not be measured with money. Law and ethics state whether the proposed system operates within legal and ethical boundaries. The operations state whether the design will be supported by those who use it. Schedule states may apply the system within the specified time constraints 


\section{B. System Analysis}

At this stage the analysis of information required by the organization, data and information sources, and the ability of the information system is expected. This analysis brings together or matching the needs of users with system operational functions. Through this stage can be known flow of information from and to interested parties. Any information and data required and provided by the user is entered into Structured Query Language (SQL) and then adjusted its information flow using the help of Data Flow Diagram (DFD) and Entity Relational Diagram (ERD). [14][15].

\section{Designing Information System}

System design stage is done to get the framework in making an application program.The program is designed to fit the company's needs and can be used by all types of users. At this stage is determined how the system can meet the information needs for users. The process of gathering information is to gather everything that relates to the needs of the user, thereby generating a flow of related information between users, including information received by users and information provided to other users. This stage determines the source and type of information to be provided to each division that requires, in such a way as to form the basis of the database management system. Database management is designed to be used as a support in decision making (decision support system) at the managerial level and division itself. In this stage two designs are produced:

a. Database design

Database design is an effective and efficient database system design in such a way that the application program is able to utilize the data base for data preparation, data management and processing as well as information delivery. This system is designed to fulfill all or part of the information the user needs [14].

b. User interface design

At this stage the interface design is required by the system in the form of detailed details of entry, editing, tracking, and reporting data. Therefore in this stage involves the design of the database that has been designed previously. Then both designs are developed simultaneously [14][15][16].

\section{Programming (coding) and verification}

Activities undertaken in this stage is programming (coding) in order to build web applications. The provision of these activities are the two previous activities of database design and user interface design. Coding begins with compiling a number of basic modules, then compile the needs of the user interface of each division. Further facilitate the need for data and information between divisions and other programming that are supportive and separate. At this stage also the results of coding directly tested to determine whether there are bugs and errors in the program. Repair coding done step by step according to the errors indicated [15][16]. After that is the application verification activity, which is doing testing to ascertain whether the program is in accordance with the system design. Program improvement is done when the result is different with system design.

\section{E. Validation and Implementation}

When the application has been verified then it can be implemented in the production system. Implementation activities are initiated by procurement and installation of hardware, installation and software development, testing programs and procedures, development of documentation and other supporting activities. After the installation process is complete, then is the activity of system validation. System validation is required on all users involved in the process of producing lettuce plants with Nutrient Film Technique (NFT) method. This is actually a test on the real system to determine the performance of the built applications. Validation is done until the system is considered to be in accordance with the actual system. After that, documentation is done which includes instructions for using the information system.

\section{RESULT AND DisSCUSSION}

\section{A. System Investigation and Analysis}

Investigation activities against the company generate a statement of problems and goals to be achieved. Currently the company still feels the slowness in delivering information between divisions, especially on the production of lettuce with NTF method, while the lettuce is a lot of in need. The desire of the company is the building of an integrated information system and more automated and accurate so as to accelerate decision making. Based on the feasibility study, the resolution of the above problems is expected to be realized.

Implementation of information systems is considered useful in corporate management.The benefit is to improve the business information flow 
of lettuce including the involvement of lettuce production activities. This application is required from activities prior to production activities ie making production forecasts, then designing targets of production. If all decisions at the initial stage (pre production) have been determined, then the decision (as information) is the basis of production related information about the type, time and quantity of the product. At the end is obtained data of production. The result data of this production activity is the basis of decision making by Manager and marketing division.

Database design begins with analyzing every actor and entity that is included in the production of lettuce plants. Each actor has their own data requirements. The identified entity raises a useful master file as the base of the transaction by creating a query that may involve a number of master files. While each actor raises the transaction file in accordance with the task of the actor assisted with the input form. The transaction file of each actor is stored in query form, processed using a specific model and the result is a report that can be viewed by the user according to authority.

Query has the function of storing the input data as a transaction file. The data stored in the query can be compiled as a report. This report is in the form of tables and can be viewed by each division and always monitored by the manager as the final report.

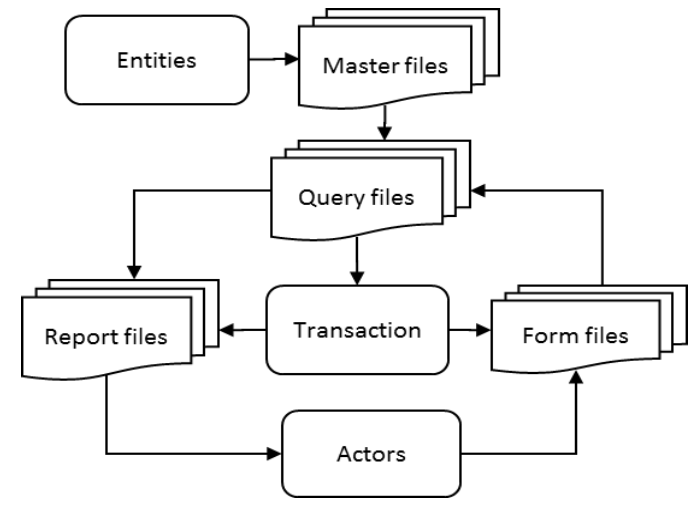

Fig. 1 The relationship of actors in managing required files

The relationship of actors involved in managing this database requires files associated with the lettuce production process. Based on entities in the system then compiled as many as 6 master files. Based on the data and information needs of each division then compiled as many as 8 transaction files and 8 report files. All files referred to are shown in Table 1.
TABLE 1

FILES IN THE DATABASE SYSTEM

\begin{tabular}{|l|l|l|}
\hline Name of File & Type of File & User \\
\hline Marketing_Master_Outlet & Master & Marketing \\
\hline Marketing_Master_Product & Master & Marketing \\
\hline Production_Master_Greenhouse & Master & Production \\
\hline Production_Master_Jenis_Item & Master & Production \\
\hline Production_Master_PIC & Master & Production \\
\hline PH_Master_Monitor & Master & Packing House \\
\hline Marketing_Transaction_PO & Transaction & Marketing \\
\hline Marketing_Transaction_Inventory & Transaction & Marketing \\
\hline Production_Transaction_Inventory & Transaction & Production \\
\hline Production_Transaction_Nursery & Transaction & Production \\
\hline Production_Transaction_N1 & Transaction & Production \\
\hline Production_Transaction_N2 & Transaction & Production \\
\hline Production_Transaction_Production & Transaction & Production \\
\hline PH_Transaction_Monitoring & Transaction & Packing House \\
\hline Marketing_Report_PO & Report & Marketing \\
\hline Marketing_Report_Inventory & Report & Marketing \\
\hline Production_Report_Inventory & Report & Production \\
\hline Production_Report_Nursery & Report & Production \\
\hline Production_Report_N2 & Report & Production \\
\hline Production_Report_Production & Report & Production \\
\hline PH_Report_Monitoring & Report & Packing House \\
\hline & & \\
\hline
\end{tabular}

The master file itself is prepared by processing corporate files that previously existed, but the files are still in one unity and not separated based on the entity and its usefulness. The files are analyzed to obtain data based on the entity and its usefulness. Then also done normalization of data. Files are also compiled based on user actors to facilitate further archiving and inspection of data. The designed files are tailored to the needs of each actor. A transaction file will appear when an event occurs. Each transaction file will retrieve data from the corresponding master file to compile the required query.

Transaction file assisted with form as media to enter data. There are a number of attributes of each actor connected in a relation and made into a data stream using Data Flow Diagrams (DFD) and Entity Relationship Diagram (ERD). Each relation will describe the entity relationship and the needs of each actor. Each actor has an association with other actors because they exchange data and information and are two-way. This data exchange is tailored to each actor's needs, the need to obtain information and provide information from and to other actors.

Managers need information from the marketing division, production division and packaging house division. The information is in the form of recap of order and recap delivery from marketing division and packaging house, while recap from production division in the form of information recap of seedling stage, nursery 1 , nursery 2 , and production stage. Information issued by the manager, among others, is information to determine the next decision for each division concerned. 
The process begins with the marketing division choosing the composition of the product and the item, then the data is entered into the form to input the buyer outlet and the order amount. This as a booking transaction file in the marketing division. This ordering data by the system will be sent to the production division and packaging division of the house so it will facilitate the two divisions in entering the next data related to the transaction data on it.

Here is a table of needs and availability of information from each actor. Each actor will need information from other actors and will provide information to other actors.

TABLE 2

THE NEEDS AND AVAILABILITY OF INFORMATION FROM EACH ACTOR

\begin{tabular}{|c|c|c|c|c|}
\hline Actors & $\begin{array}{l}\text { Need information } \\
\text { from }\end{array}$ & Information form & Send information to & Information form \\
\hline \multirow{3}{*}{ Managers } & Marketing Division & Report & Marketing Division & Message \\
\hline & Production Division & Report & Production Division & Message \\
\hline & $\begin{array}{l}\text { Packaging House } \\
\text { Division }\end{array}$ & Report & $\begin{array}{l}\text { Packaging House } \\
\text { Division }\end{array}$ & Message \\
\hline \multirow{4}{*}{$\begin{array}{l}\text { Marketing } \\
\text { Division }\end{array}$} & \multirow{2}{*}{ Manager } & \multirow{2}{*}{ Message } & Manager & Report \\
\hline & & & Production Division & Production Target (Plant / Item) \\
\hline & \multirow{2}{*}{ Consumers } & \multirow{2}{*}{$\begin{array}{l}\text { Product, Item Type, } \\
\text { Amount, } \\
\text { Schedule Booking }\end{array}$} & $\begin{array}{l}\text { Packaging House } \\
\text { Division }\end{array}$ & Production Target (Product) \\
\hline & & & Consumers & $\begin{array}{l}\text { Product Type, Amount, Delivery } \\
\text { Schedule }\end{array}$ \\
\hline \multirow[b]{2}{*}{$\begin{array}{l}\text { Production } \\
\text { Division }\end{array}$} & Manager & Message & Manager & Report \\
\hline & Marketing Division & $\begin{array}{l}\text { Production Target (Plant } \\
\text { / Item) }\end{array}$ & $\begin{array}{l}\text { Packaging House } \\
\text { Division }\end{array}$ & Production Output \\
\hline \multirow{3}{*}{$\begin{array}{l}\text { Packaging House } \\
\text { Division }\end{array}$} & Manager & Message & Manager & Report \\
\hline & Marketing Division & $\begin{array}{l}\text { ProductionTarget } \\
\text { (Product) }\end{array}$ & \multirow[t]{2}{*}{ Marketing } & \multirow[t]{2}{*}{ Product Availability } \\
\hline & Production Division & Production Output & & \\
\hline Consumers & Marketing Division & $\begin{array}{l}\text { Product Type, Amount, } \\
\text { Delivery Schedule }\end{array}$ & Marketing Division & $\begin{array}{l}\text { Product, Item Type, Amount, } \\
\text { Schedule Booking }\end{array}$ \\
\hline
\end{tabular}

\section{B. System Designing}

This stage is the stage of making the information system model that meets the needs. This stage contains the design starting from the process of application design and database design to meet the information requested users. The information system is built using PHP programming language and MySQL database which is processed in the supporting application that is PHP MyAdmin and HeidiSQL [15][16].

In the stages of database design, based on information in each transaction on each actor, then compiled a number of transaction file formats by relating a number of specific master files and input data according to their needs so that this data can be displayed into an information [14]. This transaction file exists to support input data forms and some for reporting. Each master file and transaction file are linked by using SQL Inner Join feature or commonly called SQL Join. SQL Join in the linked file of each records query in each primary key.

That way every transaction file will have a foreign key of each master file ID. The system is designed interactively to enable adding, editing, and deleting data. To describe in making of data base required a design of data flow diagram (Data Flow Diagram) and entity relationship diagram (Entity Relationship Diagram).

\section{Data Flow Diagram}

System design is done by using flowchart method in the form of Data Flow Diagram (DFD). DFD in Figure 2. is a DFD level 0 or DCD (Data Context Diagram) by showing the four entities (Manager, Marketing, Production, and Packaging House) then decomposed into level 1 with three processes (predict production data, process production data and process sales data).

At the design stage of production data processing, we do decomposition to level 2. The flow of data begins from the division of Marketing where the division is forecasting the production process. The data is then received by the Production Supervisor and then will get the data of production is processed together with Administrator. The data will then be given to Packaging House to facilitate the processing of sales data later. The data will be re-accepted by Marketing in order to make product forecasting in the next period. 


\section{Database Designing}

In database design, we use database table format. This database table can be the storage of previously grouped data. Each table will describe each file, data type, width, and its relation by using primary key and foreign key. Identification of files can facilitate the design of the database. The file name attribute specifies the name of the attribute contained in the database, the data type specifies the type of the attribute, the length / set represents the width of the data type, the description specifies the description of the attribute, the primary key represents the primary key, the foreign key represents the foreign key .

\section{A. Entity Relationship Diagram (ERD)}

Conceptual design of data needs and relationships between data on this information system using Entity Relationship Diagram (ERD). By using this diagram we get a model of a notation symbol that visualizes the data on each entity and the relationships between these entities [14].

The relationship contained in this entity relationship diagram is composed of master files and transaction files from the divisions of marketing, production, and packaging house. Each file is linked by the file type and the user of the file. Transaction files will be linked from marketing as upstream. Each file connected to each other has one to one and / or one to many links. The ERD is arranged as shown in Figure 2.

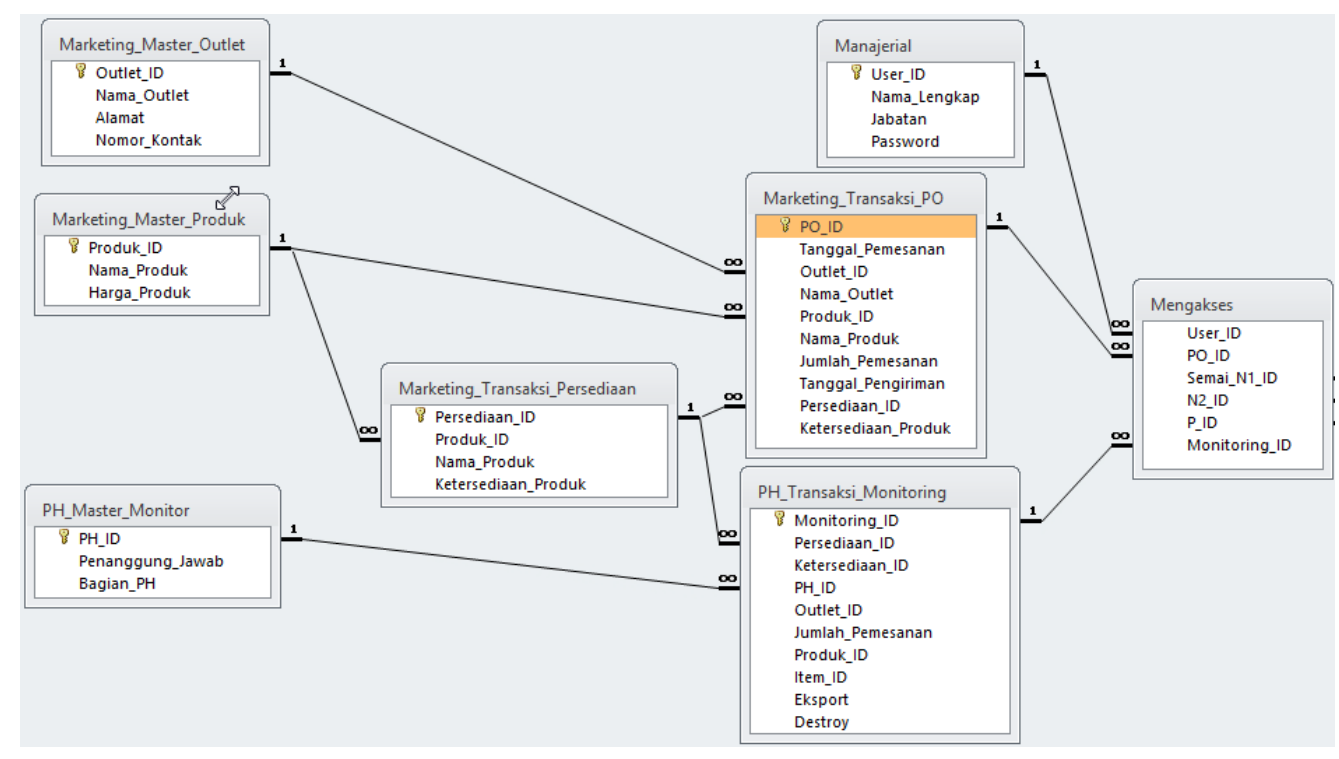

Fig. 2 ERD for manager, marketing division and packaging house division

In the design of information sourced from the database, necessary relationships between files. The relationship between files using SQL Join, which is a way to connect each file by using the entity parameters to be retrieved. This stage begins by designing a foreign key index that leads to the master file on the receiver table. In this stage it is necessary to normalize the data so that each file can be arranged correctly and efficiently.

In the master file of products and items both will be received by the data of each transaction file, this is because the product data and items are data that become parameters in this information system, from the ordered product along with the type of items of the ordered product.

\section{E. Information Structure}

The structure view describes the menu structure of the website application. The main menu is the first page with the login menu of each division and comes with a schedule feature and website introduction. Each division has a role to input the database and can view the recap results in each division's report and only the manager can view the recap reports of each division and can comment on the division. The website structure in Figure 3 below explains how the view is sorted by the site map compiled with the main menu home page which is the main gateway to enter this website. 


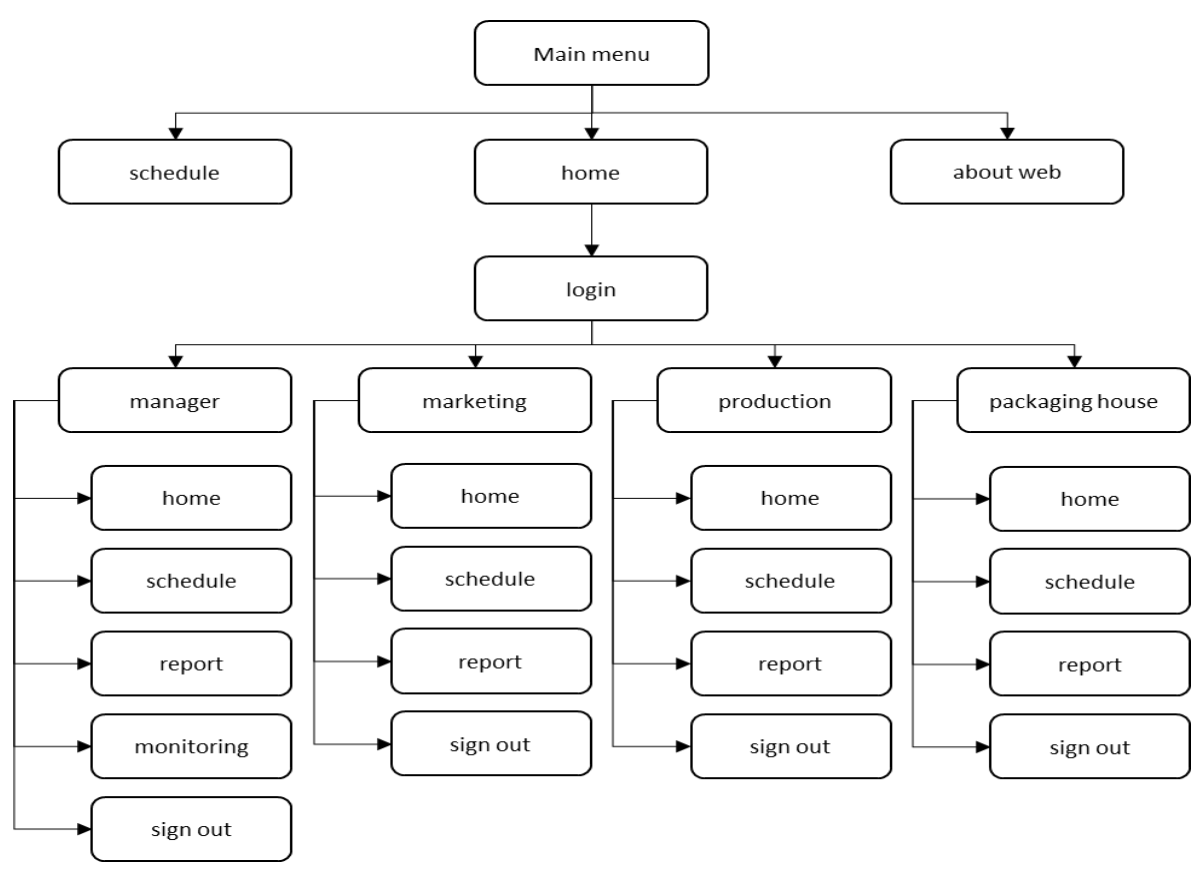

Fig. 3 Web information structure

\section{F. Database Management}

Database managed information systems in the design of this website application has a feature to perform database management. Database management features need to be added to this website because each data must be entered, stored in the database (save), accessed as a report (output), database changes (edit), and can be deleted. Apart from these features, there is also a feature search database (search) in order to facilitate the user when accessing the database. Figure 4 show the relation between all type of action indatabase management.

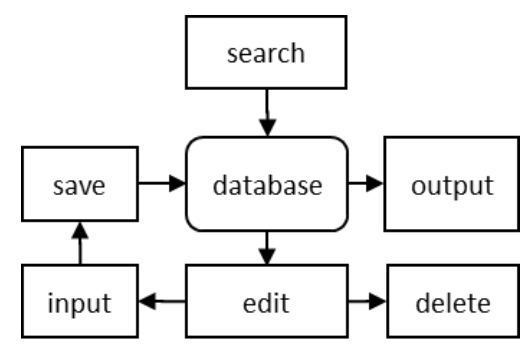

Fig. 4 Database management scheme

Each feature has its own role in database management. The input feature has a function to enter any data that the user enters through the form. After the user fills the entire contents of the form, then the save feature serves as a data storage feature. The data already entered through the form will be moved into the database. The data already entered into the database can be called through the output feature. At the output stage, the database will be invoked with a report database view.

Additional features contained in the website application system is a search feature. The search feature is useful when the user searches the data. Users simply enter the keywords only then the system will work to do a search of related keywords. In addition, users can also use the editing features, features that can be used by the user when a database when it is necessary for a change so that the user can replace the previous database to the new database. If the user does not need unused data, then the user can use the delete feature to delete the data.

\section{G. System Testing}

During the design of this information system, there have been some changes for the website to be better. Many times the change happens because in every test there is always a mistake and incomplete which encourages the improvement and addition. Repeated testing occurs in the database management section. System test is done by using black box method. Black box testing is done to check the functionality of coding design programming application system. In the design of this system found some bugs (defects) on the design of coding programming application system. Testing 
done up to 30 times so that in the end the information system can run in accordance with the minimum expectations.

\section{CONCLUSION}

The conclusion of this research is the successful development of a website-based information system application as a database management designated for manager, marketing division, production division, and packaging division of house in PT X.

The application of the information system provides added value in the form of an increase in information speed, information accuracy and information archiving. In addition, more structured and easier data management in the processing and management of data will be obtained. The aspects of information and managed data cover marketing aspect, greenhouse activity (nursery, nursery 1, nursery 2, and production), processing and packaging.

\section{REFERENCE}

[1] A.J.S. Neto, S. Zolnier, and D. C. Lopes, Development and Evaluation of An Automated System for Fertigation Control in Soilless Tomato Production, Computers and Electronics in Agriculture, 103:17-25., 2014.

[2] D.S. Domingues, Hideaki W. Takahashi, C A. P. Camara, and S.L. Nixdorf. Automated System Developed to Control Ph and Concentration of Nutrient Solution Evaluated in Hydroponic Lettuce Production, Computers and Electronics in Agriculture 84:53-61, 2012.

[3] D.Z. Vidianto, S. Fatimah and C Wasonowati, "Penerapan Panjang Talang dan Jarak Tanam Dengan Sistem Hidroponik NFT (Nutrient Film Technique ) Pada Tanaman Kailan (Brassica oleraceae var. alboglabra)", Agrogivor 6(2):128-35, 2006.

[4] R. Rosliani, and Nani Sumarni, Budidaya Tanaman Sayuran dengan Sistem Hidroponik. Balai Penelitian Tanaman Sayuran Pusat Penelitian Dan Pengembangan Hortikultura, Badan Penelitian Dan Pengembangan Pertanian, Lembang., 2005.

[5] D. Läpple, A. Renwick, J. Cullinan, and F. Thorne, What Drives Innovation in The Agricultural Sector? A Spatial Analysis of Knowledge Spillovers" Land Use Policy 56:238-50, 2016.
[6] J.A. O'Brien, and G. M. Marakas. Management Information System $10^{\text {th }} \mathrm{ed}$. New York: McGraw Hill, 2011.

[7] T.D. Wilson, "On User Studies and Information Needs." Journal of Documentation 37(1):3-15, 1981

[8] M.S. Palmquist, M.A. Lapham, S. Miller, T. Chick, and I. Ozkaya, Parallel Worlds: Agile and Waterfall Differences and Similarities, Pittsburgh: Carnegie Mellon University, 2013.

[9] M. McCormick, "Waterfall and Agile Methodolo-gy", MPCS Inc (8/9/2012):1-8., 2012.

[10] C.R. Kothari, Research Methodology, Method \& Technique 2nd Revised Edition, New Age International (P) Limited, Publishers, New Delhi,

[11] F. Constantianus, and B.R. Suteja, "Analisa dan Desain Sistem Bimbingan Tugas Akhir Berbasis Web dengan Studi Kasus Fakultas Teknologi Informasi." Jurnal Informatika UKM 1(2):93-105, . 2005.

[12] R.S. Pressman, Software Engineering a

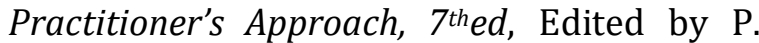
Ducham, New York: McGraw Hill, 2009

[13] T. Connolly, and C. Begg, Database Systems: A Practical Approach to Design, Implementation, and Management $4^{\text {th }}$ ed, Addision Wesley, 2005.

[14] R. Afyenni, "Perancangan Data Flow Diagram untuk Sistem Informasi Sekolah (Studi Kasus Pada SMA Pembangunan Laboratorium UNP)", Teknoif 2(1):35-39, 2014

[15] K.M.S. Haryana, "Pengembangan Perangkat Lunak dengan Menggunakan PHP." Jurnal Computech \& Bisnis 2(1):14-21, 2008.

[16] A. Kadir, Dasar Pemrograman Web Dinamis Menggunakan PHP, $3^{\text {rd }}$ ed. Yogyakarta: Penerbit Andi, 2008. 